\title{
Family help received by Mexican older adults across socioeconomic strata: changes over a critical decade
}

\author{
Karina Orozco-Rocha, ${ }^{1}$ Cesar Gonzalez-Gonzalez, ${ }^{1}$ and Rebeca Wong ${ }^{2}$
}

Suggested citation Orozco-Rocha K, Gonzalez-Gonzalez C, Wong R. Family help received by Mexican older adults across socioeconomic strata: changes over a critical decade. Rev Panam Salud Publica. 2021;45:e90. https://doi.org/10.26633/RPSP.2021.90

ABSTRACT Objective. To identify how patterns of family economic support help alleviate the cumulative effects of inequality, with focus on the financial support that children give their elderly parents.

Methods. This paper uses data from two cross-sections, 2001 and 2012, of the Mexican Health and Aging Study for the 50 years and older population. Analysis includes descriptive statistics to estimate differences in economic support based on family and individual characteristics; and a multinomial probit regression model, in each cross-section, to analyze the amount of money received for economic help and the associated characteristics.

Results. Economic help received was significantly reduced, both in proportion, from $20 \%$ to $10 \%$ between 2001 and 2012, and in the amount received, with differences by income quintile. In 2001, 14.9\% of those in the lowest quintile (Q1) would move to Q4-Q5 with children's help; in 2012, this was 9.1\%. The adjusted probability of receiving any amount of money from children decreased from 0.511 in 2001 to 0.340 in 2012.

Conclusions. In Mexico, economic inequality in the 50 years and older population remains a constant. Economic help received from children varied by income quintile and plays an important role for those in the lowest income groups. More research is needed to understand the patterns of intergenerational exchanges as these cohorts of older adults continue to age and as future cohorts are entering old age with more pronounced changes than the current cohorts experienced over this critical decade.

Keywords $\quad$ Family; population dynamics; economics; Mexico.

In most developing countries, adult children traditionally support older parents through co-residence or by providing economic and non-economic help (1). Mexico provides a clear example of such family relationships. Prior research has shown that adult children are an important source of support when parents have economic and health care needs, and they become increasingly important at older ages (2). But family relationships in Mexico are changing, as the average number of children has declined, with unknown consequences on the patterns of multi-generational co-residence and old-age support.

Research on the topic of old-age support provided by the family has mostly been carried out in the United States of America and European countries (3-5), and less is known of countries like Mexico, where adult children are an important component

\footnotetext{
1 University of Colima, Colima, Mexico $\bowtie$ Cesar Gonzalez-Gonzalez,
} cgonzalez31@ucol.mx of the parents' networks for support in old age (6). In Mexico, those receiving economic transfers from family are the oldest individuals, women without spouses, and those living in rural localities (7-9).

Several structural changes in Mexico have also been reshaping familial relationships and may impact the economic well-being of older adults. The first of these is a dramatic increase in educational achievement (10). Second, over the decade 2000-2010, the Mexican Government enacted two social programs, the Seguro Popular (medical insurance) and Programa 70 y Más (non-contributory pension, at first for those aged 70+, now 65+). The medical insurance program aimed to provide universal access to health services, especially for the most vulnerable populations, while the $70+$ pension program has a direct impact on the

\footnotetext{
2 University of Texas Medical Branch, Galveston, United States of America
} 
income of older adults. Mexico is a large country experiencing fast population aging in the 21st century, while still having a limited infrastructure and scarce institutional support for old age, as well as historically high social and economic inequality. For example, over their life course, a high percentage of individuals worked in the informal sector, leading to disadvantages in old age. In 2014, three-quarters of the 60 years and older population was living in poverty, only one-fifth received a contributory pension, while one-third received a non-contributory pension (11). Furthermore, $46 \%$ of men and $15 \%$ of women aged 60 and older were still working to support themselves and their family (2). Financial markets are not sufficiently developed in Mexico, thus, beyond labor, alternative sources of income in old age are quite limited $(7,12)$. Moreover, the historically high migration between Mexico and the United States of America contracted substantially over the decade 2000-2010, reducing the remittances that are an important source of income for families in Mexico.

The goal of this paper is to identify how patterns of family economic support help alleviate the cumulative effects of inequality. To do this, the focus is on the financial support that children give to their elderly parents, and in particular on these questions: What are the observed patterns of help received by the elderly across socioeconomic groups, and did this help change over the critical 2000-2010 decade? How critical as a source of income is family help in support of old age, and does this relative importance vary across socioeconomic groups?

\section{MATERIALS AND METHODS}

This descriptive cross-sectional study used publicly available data from the Mexican Health and Aging Study (MHAS), a national longitudinal study started in 2001 and with four waves of information (13). The main objective of the MHAS is to provide data to permit the examination of the aging process in Mexico and the disease burden and disabilities of older adults from a broad sociodemographic and economic perspective. This paper uses data from two cross-sections, 2001 and 2012 , both representative of the population aged 50 and older in Mexico. The analysis included individuals aged 50 years and older with at least one child alive and with a completed direct interview. The final sample size included 11715 individuals in 2001 and 12763 in 2012. The focus is on the differences across socioeconomic groups in the economic support provided by adult children to their elderly parents.

\section{Dependent variables}

Economic support is captured at the individual or couple (if applicable) level; that is, the financial support received by the selected person (and his/her spouse, if any) from their children. The information is obtained through the question: "In the last two years, have you (or your spouse) received help in money or in kind from any of your children and/or grandchildren (and those of your spouse)?" The variable was coded 1 if the person received economic support from their children and 0 otherwise.

The monthly amount of economic help received by the person (or couple) from their adult children was also measured. If the information referred to a couple, then the amount was divided by two to obtain a per capita measure. The question refers to "How much money was that help in total, in the last two years?" A variable with four ordered categories was created: 1) not received economic help; 2) received a small amount of economic help (Mex\$1 to Mex\$ 200 in 2001); 3) received a medium amount of economic help (Mex\$ 201 to Mex\$ 1000 in 2001); and 4) received a large amount of economic help (more than Mex\$ 1000 per month in 2001). ${ }^{1}$ Similar categories were created for 2012, adjusting the amounts and cut-off points by inflation rates to make them comparable across time. The amounts are expressed in 2001 pesos.

\section{Independent variables}

Because the focus of this research is to examine the likelihood that older parents receive financial help from their children, and how it varies across socioeconomic strata, the principal explanatory variable represents income groups. For this purpose, only non-family income is considered. MHAS questions about salaries or self-employed work, pensions, other non-family transfers, and income derived from property and from financial assets were used to construct quintile categories.

The analysis controlled for variables capturing the older adults' family network, health, and sociodemographic characteristics. The family network variables were: survival status of the older adults' parents (yes, no); number of surviving children (1-3, 4-6, 7+); living arrangements (alone/with spouse, with non-working children, with working children, with children and others, with other relatives); ${ }^{2}$ and children living in the United States of America (yes, no). Health variables were: self-rated health status (fair/poor versus excellent/very good/ good) and access to health care services (yes, no). Finally, the sociodemographic characteristics were: sex; age (50-59, 60-69, 70-79, 80+); years of formal education (none, 1-5, 6, 7+); marital status (with or without spouse); and receipt of old-age pension (none, contributory, and non-contributory pension).

The analysis includes descriptive statistics with chi-square tests to estimate differences in economic support based on family and individual characteristics; a multinomial probit regression model in each cross-section, with economic help received in categories of amount as dependent variable. Using the results of the regression models, the marginal effects (ME) were calculated for ease of interpretation. Stata 15 software package was used for the analyses. The MHAS surveys were implemented by the National Institute of Statistics and Geography (INEGI). All analyses relied on publicly available, anonymized datasets.

\section{RESULTS}

\section{Sociodemographic changes and economic inequality across a decade}

Table 1 shows individual and family descriptive characteristics of the population aged 50 years and older according to economic, health, sociodemographic, and family characteristics in 2001 and 2012. The most significant differences in this decade

1 To provide context, the non-contributory pension received by one-third of the elderly is Mex\$585 per month on average. Another $20 \%$ received a contributory pension of Mex\$ 6169 monthly on average (8).

2 The variable of living arrangements captures the pressure on resources that older adults have; we assume that the 50 years and older population living with non-working children are in consolidation stages of the household, while those living with their working children are in the expansion stage, giving children the possibility of providing economic support to parents. 
TABLE 1. Descriptive characteristics of the population 50 years and older with surviving children, Mexico, 2001 and 2012

\begin{tabular}{|c|c|c|c|c|c|}
\hline Characteristics & $\begin{array}{c}2001 \\
(\%)\end{array}$ & $\begin{array}{c}2012 \\
(\%)\end{array}$ & Characteristics & $\begin{array}{c}2001 \\
(\%)\end{array}$ & $\begin{array}{c}2012 \\
(\%)\end{array}$ \\
\hline Sex & & & Pension access & & \\
\hline Women & 53.9 & $54.2^{\mathrm{c}}$ & Yes & 8.1 & 17.5 \\
\hline Age & & & Surviving parents & & \\
\hline $50-59$ & 46.6 & $45.8^{c}$ & No & 72.5 & 64.0 \\
\hline $70+$ & 22.6 & $22.0^{c}$ & No. of surviving children & & \\
\hline Years of formal education & & & $1-3$ & 28.8 & $42.7^{c}$ \\
\hline None & 30.8 & $16.9^{c}$ & $4-6$ & 37.3 & 36.9 \\
\hline $1-5$ years & 35.1 & $29.7^{c}$ & $7+$ & 33.9 & $20.4^{c}$ \\
\hline 6 years & 15.9 & $21.5^{c}$ & Living arrangements & & \\
\hline 7 or more & 18.2 & $32.0^{c}$ & Alone/with spouse & 22.3 & $26.6^{c}$ \\
\hline Locality of residence & & & Other relatives & 8.2 & 6.9 \\
\hline Less urban & 52.8 & 50.7 & Children living in U.S. & & \\
\hline More urban & 47.2 & 49.3 & No & 75.6 & $81.7^{c}$ \\
\hline Self-reported health & & & Yes & 24.4 & $18.3^{c}$ \\
\hline Excellent, very good, or good & 36.3 & 36.7 & Economic help received & & \\
\hline Fair or poor & 63.7 & 63.3 & Not received & 48.4 & $67.1^{\mathrm{c}}$ \\
\hline Health care access & & & Small & 24.1 & $9.4^{c}$ \\
\hline No & 46.8 & $14.2^{\mathrm{c}}$ & Medium & 16.6 & 16.9 \\
\hline Yes & 53.2 & $85.8^{c}$ & Large & 10.9 & $6.6^{c}$ \\
\hline \multicolumn{6}{|c|}{ Income quintile (non-family income) } \\
\hline 1 & 25.2 & $32.8^{c}$ & & & \\
\hline
\end{tabular}

Note: ${ }^{\mathrm{a}} p<0.05,{ }^{\mathrm{b}} p<0.01,{ }^{\mathrm{c}} p<0.001$; U.S., United States of America

Source: Calculations by the authors using data from the Mexican Health and Aging Study, 2001 and 2012. Weighted statistics.

were: compared with 2001, a higher percentage of older adults had surviving parents in $2012(64.0 \%$ versus $72.5 \%)$, a lower percentage had $7+$ children alive (falling from $34 \%$ to $20 \%$ ), the share without formal education fell from $30.8 \%$ to $16.9 \%$, and access to health care increased from $53.2 \%$ to $85.8 \%$. The latter change was driven mostly by the health care reform and the creation of the Seguro Popular program. The percentage receiving a contributory pension doubled from $8.1 \%$ to $17.2 \%$, while the 2012 cohort had a higher proportion $(32.8 \%)$ in the lowest income quintile compared with $2001(25.2 \%)$; that is, a higher portion of older adults living under economic stress.

Economic inequality among the population aged 50 and older was evident. In 2001, the highest (richest) quintile concentrated $80.8 \%$ of total income held by this population, an inequality that seemed to deepen somewhat by 2012, when the top quintile concentrated $84.7 \%$ of the total income (data not shown).

\section{Differences by socioeconomic strata}

Economic help received from children as a share of the total income of older adults decreased on average from $20 \%$ to $10 \%$ between 2001 and 2012, with variations across income quintiles (Figure 1). For the first and fourth quintile, the relative contribution did not change for those years; for quintiles 2 and 3, the contribution to the total income increased, and it decreased for the highest quintile. Thus, the overall decrease in total income was related to the decline among those in the highest quintile: economic help received from children in the fifth quintile went from $17 \%$ to $5 \%$ of their total income.

Figure 2 shows the differences in the monetary amount of help received across income quintiles. There was no difference in 2001 , as $42.0 \%$ of those receiving economic help from children in the first quintile received a small amount of money, and the percentage was similarly $47.8 \%$ for those in the fifth quintile. In 2012, although the differences were a bit larger, the pattern was not clear or slightly pointed toward the higher income quintile receiving a greater amount of economic help.

To examine the relative importance of family help on economic well-being, income quintiles were calculated based on total non-family income. Using the ranges obtained for each quintile, the population was re-ordered by total income, now including family income. The intent was to assess the extent to 
FIGURE 1. Mean non-family income and family income by income quintile, adults aged 50 and older, Mexico, 2001 and 2012 $\left(\right.$ Mexican pesos $\left.{ }^{a}\right)$

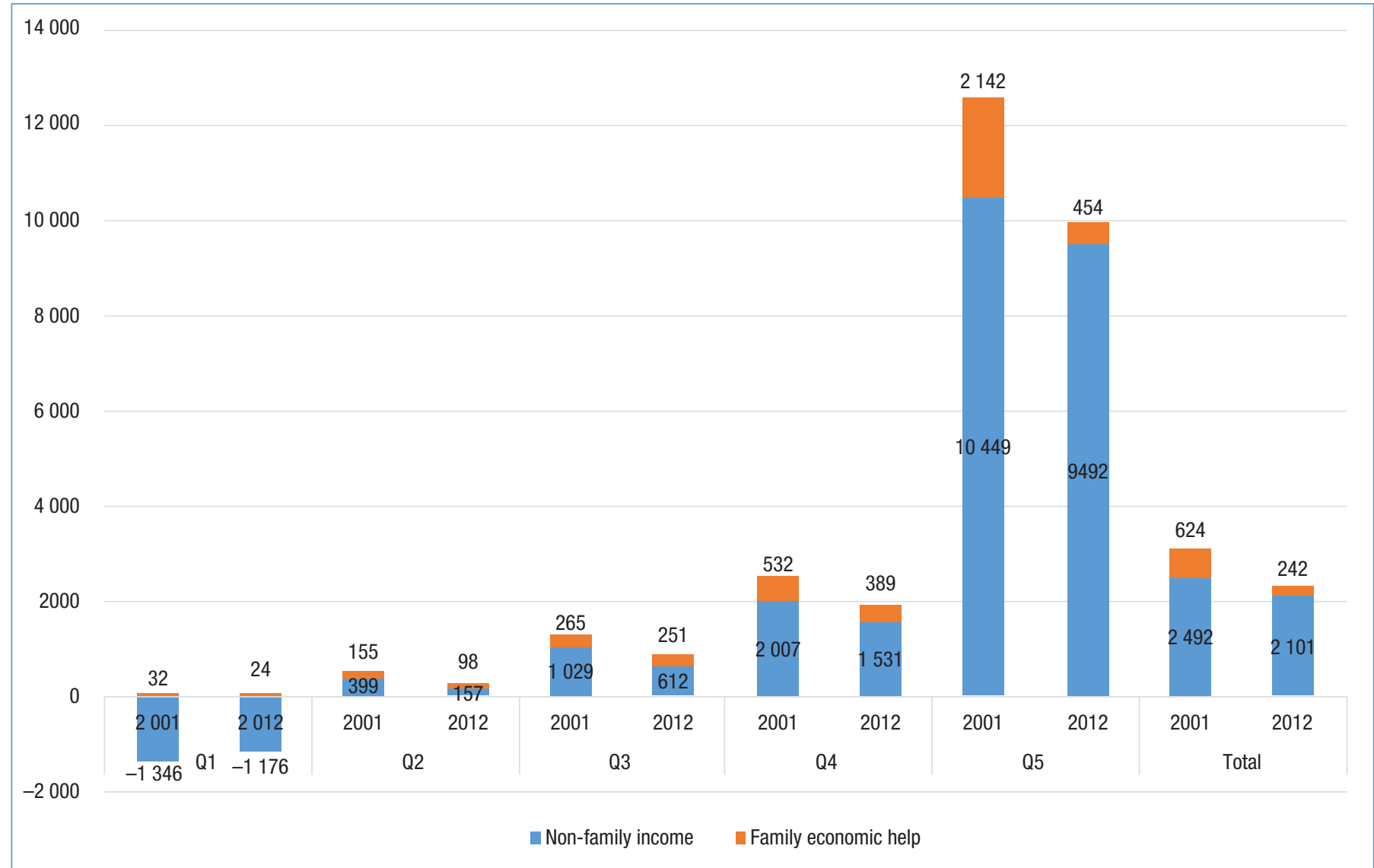

Note: ${ }^{a}$ Amounts are annual, adjusted for inflation, expressed in 2001 pesos (Mex\$). Monthly minimum wage $=$ Mex\$1210. Source: Calculations by the authors using data from the Mexican Health and Aging Study, 2001 and 2012. Weighted statistics.

FIGURE 2. Percentage of adults aged 50 and older receiving economic help from children by amount received and income quintile, Mexico, 2001 and 2012

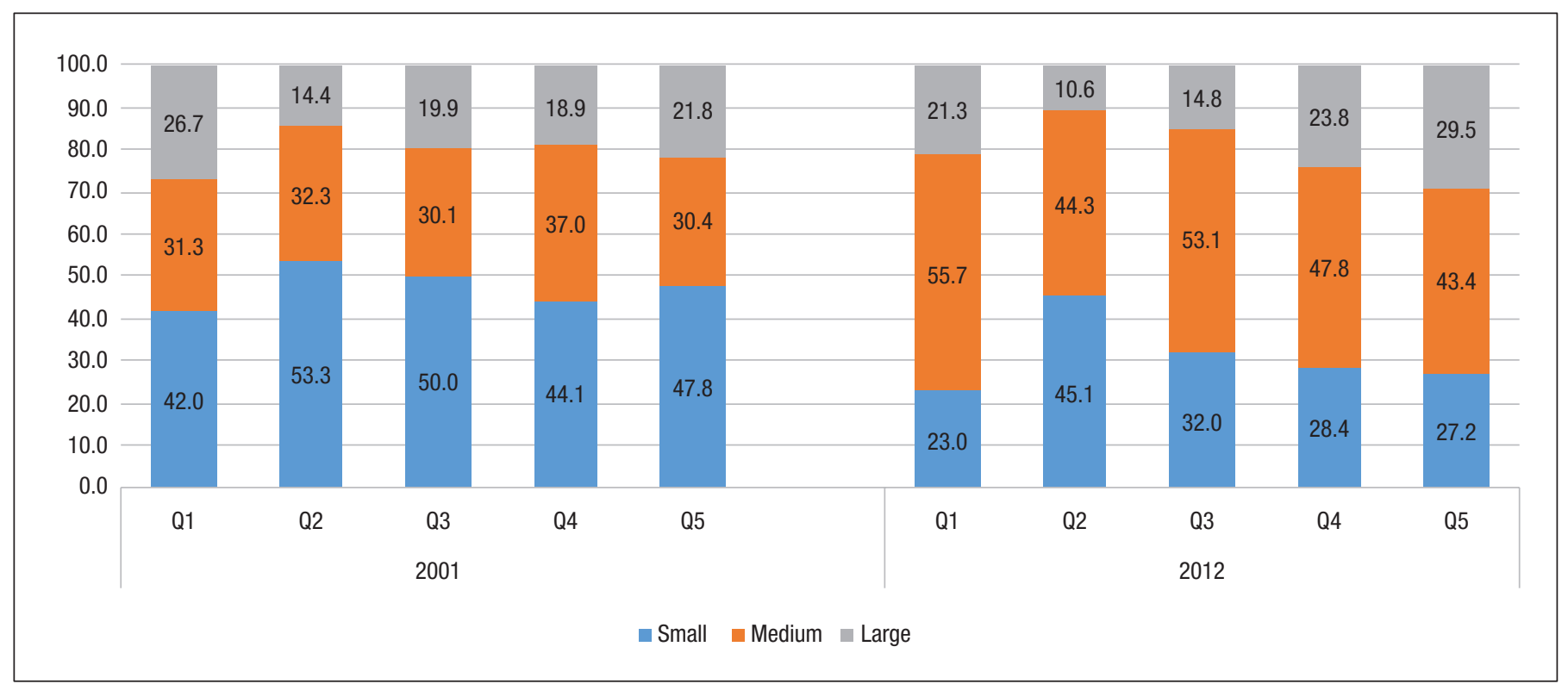

Note: a Amount received refers to small ( $\leq$ Mex\$200), medium (Mex\$ 201 to Mex\$1 000) and large (> Mex\$1 000) monthly amounts received in 2001 pesos. Income quintile using total non-family income in 2001 and 2012, respectively,

measured in 2001 pesos. Q1 is the lowest and $Q 5$ is the highest income.
Source: Calculations by the authors using data from the Mexican Health and Aging Study, 2001 and 2012. Weighted statistics. 
FIGURE 3. Distribution of population aged 50 years and older according to non-family income quintile, by quintile to which they would move if family help is considered part of income, Mexico, 2001 and 2012a

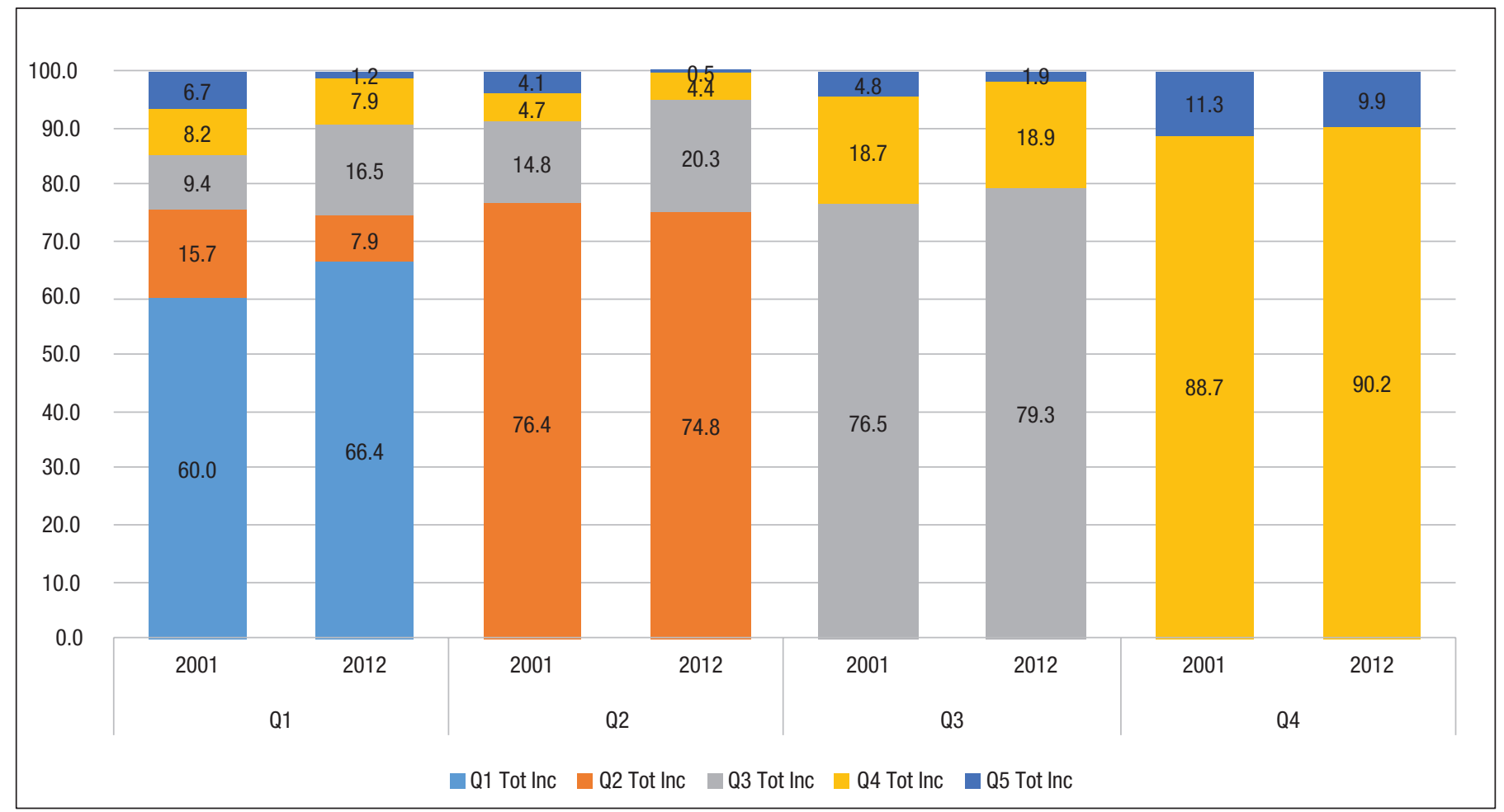

Note: ${ }^{\text {a }}$ Quintile 5 is not shown in the graph because those individuals who are already included in it cannot move up to a higher quintile. Source: Calculations by the authors using data from the Mexican Health and Aging Study, 2001 and 2012. Weighted statistics.

which the amount of income received from children shifted individuals/couples into a higher income quintile. For example, in 2001 among those in the first (lowest) quintile, 60.0\% stayed in the same quintile when family help was included, $15.7 \%$ moved up to the second quintile, $9.4 \%$ moved into the third quintile, $8.2 \%$ to the fourth quintile, and $6.7 \%$ reached the highest quintile (Figure 3). By comparison, in 2012, help from children was lower, such that $66.4 \%$ of those in the poorest quintile remained in this same group even with income from children. In 2001, $14.9 \%$ of those in the lowest quintile (Q1) moved to Q4-Q5 with their children's help; in 2012, this was only 9.1\%.

\section{Amount of economic help received}

To analyze the amount of money received, separate ordinal probit models for 2001 and 2012 were estimated. The adjusted probability of receiving any amount of money from children decreased between 2001 (0.511) and 2012 (0.340). In consequence, the probability of receiving a small amount of money also decreased from 0.235 in 2001 to 0.105 in 2012; the probability of receiving a large amount of money similarly fell from 0.103 in 2001 to 0.063 in 2012. In just a decade, the economic help received was significantly reduced, both in the proportion of older adults who received it and the amount received (Table 2).

The probability of receiving economic help by sociodemographic characteristics was estimated according to each category of the variables analyzed. In 2001, those with children living in the United States of America had the highest probability of receiving economic help (0.613); it was also the highest in 2012 (0.424), albeit lower than in 2001. This drop represents a significant reduction, possibly related to the 2008 economic crisis and the subsequent decline in remittances from the United States of America to Mexico.

Across quintiles of non-family income of the older parents, the probability of receiving economic help from children was highest among those in the first (poorest) quintile (0.626) compared with those in the fifth (0.382). In 2012, the difference in probability of receiving help was not significant among the bottom three quintiles (Table 2). In 2001, the difference in the probability of receiving help between the first and fifth quintile was around 0.245 , but in 2012 the gap was only about 0.086 ; this closing gap could be related to the generalized drop in economic help received by all income groups. The group in the first (lowest) quintile of non-family income had the greatest decrease in the probability of receiving economic help from their children between 2001 and 2012. On the other hand, those with the smallest decrease in the likelihood of receiving help from children over the period 2001-2012 were those aged 70 years and older.

For both 2001 and 2012, several characteristics were significantly related to economic help received. Women, those without a spouse or partner, and having more surviving children were associated with a higher probability of receiving economic help from children. Those who lived with working children were the most likely to receive such help; thus, this type of living arrangement may capture family solidarity. 
TABLE 2. Estimated probabilities from ordinal probit models of receiving economic help from children, Mexico, 2001 and 2012

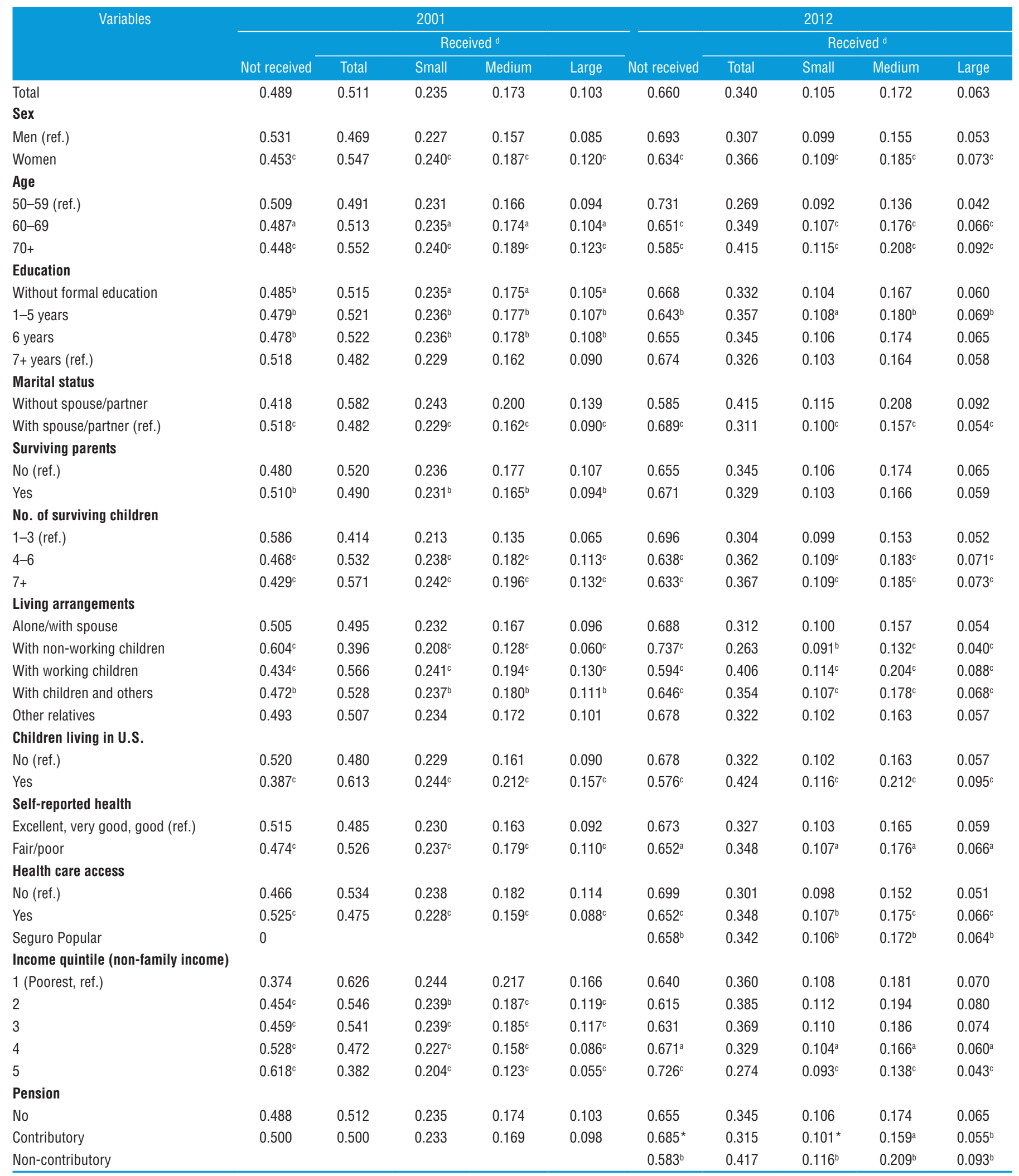

Note: Significance: a $p<0.05$, ${ }^{b} p<0.01,{ }^{c} p<0.001$; d Economic help received from children refers to small ( $\leq$ Mex\$200), medium (Mex\$201 to Mex\$1 000), and large (> Mex\$1 000) monthly amounts, received in

2001 pesos; Ref., reference; U.S., United States of America. 
In 2012, but not in 2001, older age was associated with higher likelihood of receiving economic help. The estimated probability was 0.269 for the youngest group, compared with those aged 60-69 (0.349) and those 70 and older (0.415). There was practically no difference by educational attainment, and receiving a pension was also not associated with economic help received in 2001.

\section{DISCUSSION}

Evidence confirmed that the population of adults aged 50 and older was quite different in Mexico in 2012 compared with 2001. By 2012, this population on average had fewer living children, was more educated, and was more likely to have health insurance and old-age pension. Regarding their income, however, a higher percentage of adults aged 50 and older was in the poorest income groups by 2012.

With respect to the observed patterns of help received from their children across socioeconomic groups, the findings indicate a significant and generalized drop over the decade in both the propensity to receive help and the amounts received. The help from children seemed to follow a progressive pattern in 2001, whereas those in the lowest income group had the highest probability of receiving help from children. However, this was no longer the case in 2012. Regarding disparities, the generalized drop in help from children seemed to close the gap across income groups in the propensity to receive help. Thus, two distinct patterns emerged over the decade: there was less disparity across income groups in the economic help they received from their children, but also a general drop in help received was evident, which was most acute for the low income groups.

With respect to the relative importance of children's help toward the economic position of older adults, the findings support that, despite the falling trend, children's help as a share of the older adults' total income was still a meaningful contribution in 2012 - on average about $10 \%$. On the other hand, the drop in children's help also meant a loss in their relative position: fewer older adults could shift into a relatively higher group of the income distribution with their children's economic help by 2012.

Three possible explanations can be speculated for the generalized drop in help: a better economic situation of the older adults (with less need for help); a worse economic situation of the children (with less ability to provide help); and lower willingness of children to give economic help to their parents. In general, though, the total income (in real terms) of the elderly population was lower in 2012 than in 2001, while the self-reported economic situation of their children remained equal. It is possible that, by 2012, adult children (mistakenly) perceived that their parents needed their help to a lesser extent than in 2001, because health insurance and pension reforms were launched in the country. These findings point to the need for further research on the economic situation of both older adults and their children, in order to better understand the dynamics of intra-family economic exchange $(3,14)$.

It is also possible that the observed drop was due to the sociodemographic changes that took place between 2001 and 2012, which were also closely associated with the economic help received. The findings indicate that for both years, those who had more children, women, those without a spouse or partner, and those co-residing with children were more likely to receive financial help from children. These findings are also consistent with previous research $(5,15,16)$. Thus, it would be critical to continue to examine the patterns of financial assistance from children, in particular for those in the low income groups, as these demographic changes continue to become even more pronounced in future cohorts of older adults.

Intergenerational ties are becoming a fundamental topic of research in other countries $(10,13,14)$, and with all the reported changes occurring in Mexico, it is necessary to deepen understanding of the economic support in a context where inequality is evident in myriad dimensions, but in particular in the institutional support (health care and non-contributory pensions) for old age. This is critical, as the intergenerational ties between older Mexican adults and their children, at least as documented here by economic help, may possibly be weakening.

Our research confirms that the economic help received from children is associated with the socioeconomic status of the elderly (15), that this help is vital for this age group, and that it represents an important part of the total income. The MHAS questionnaires include two questions about perceptions of economic help received: the first asks if the economic help received is sufficient, and the second inquires about beliefs in counting on this kind of help in the future. Regarding the first question, around $60 \%$ of those in the first (poorest) quintile said that the economic help received from children was enough or more than enough, with a slightly higher percentage among those in the fifth quintile. For the second question, the answer had the same direction: $50 \%$ of those in the first quintile were confident that they would receive this type of help in the future, in comparison with $60 \%$ of those in the fifth quintile. Certainly, the perception is positive, as more than half of the population considers that this help is enough or more than enough, even though the economic help received from children represented only $20 \%$ of the total income received by older adults in 2001 and 10\% in 2012.

Finally, despite structural changes occurring rapidlyseveral with the potential to improve the economic position of older adults - inequality and poverty in old age seem to persist over time, when health care needs are accentuated. Future generations of the elderly could be in worse conditions, as $65 \%$ of the adult population is currently working in the informal sector, with low income and no social security benefits.

With respect to the study's limitations, the data on financial help is self-reported by older adults and it may suffer from recall bias. In addition, it is possible that the elderly population under-reported their income (17), which could bias the results and conclusions of the study. Nevertheless, the study's principal strength relies on the comparison of two cohorts 11 years apart, and the insights gained allow a better understanding of the changes in economic help from children to their older parents over a decade of rapid population aging and enactment of important social programs in Mexico.

\section{Conclusion}

In Mexico, the economic inequality among the 50 years and older population remains a constant, while economic help received from children varied by income quintile and plays an important role for those in the lowest income groups. Despite all the social, family, and individual changes over the last 15 years, family support remains an important source of support for the elderly population. 
In terms of public policy, programs and policies need to continue to improve the conditions of younger cohorts of adult children, with better jobs and equal opportunity to social protection, robust financial markets that enable savings, and efforts to diminish the persistent inequality and poverty as they reach old age.

Author contributions. KOR, RW, and CGG developed the idea. KOR performed the data analysis, interpreted the results, and drafted the manuscript. CGG and RW contributed to the design of the study and did a critical review of the content. All authors reviewed and approved the final version.
Acknowledgment. The authors acknowledge support from the WHO/PAHO Collaborating Center on Aging and Health at the University of Texas Medical Branch (UTMB). The MHAS is funded by the NIA/NIH (grant R01 AG018016) and the Instituto Nacional de Estadística y Geografía (INEGI) in Mexico.

Conflict of interest. None declared.

Disclaimer. Authors hold sole responsibility for the views expressed in the manuscript, which may not necessarily reflect the opinion or policy of the RPSP/PAJPH and/or PAHO.

\section{REFERENCES}

1. Lin JP, Yi CC. Filial norms and intergenerational support to aging parents in China and Taiwan. Int J Soc Welf. 2011;20(Suppl. 1):109-20.

2. Aguila E, Diaz C, Fu MM, Kapteyn A, Pierson A. Living Longer in Mexico [Internet]. [Santa Monica, CA]: RAND; 2011. Available from: https://www.rand.org/pubs/monographs/MG1179.html

3. Mazzotta F, Parisi L. Money and time: what would you give back to me? Reciprocity between children and their elderly parents in Europe. Econ Polit. 2020;37(3):941-69. https://doi.org/10.1007/ s40888-020-00181-W

4. Moreno Mínguez A. Understanding the Impact of Economic Crisis on Inequality, Household Structure, and Family Support in Spain from a Comparative Perspective. J Poverty. 2017;21(5):454-81. https://doi.org/10.1080/10875549.2017.1348422

5. Albertini M. Ageing and Family Solidarity in Europe: Patterns and Driving Factors of Intergenerational Support. Policy Research Working Paper No. 7678. Washington, DC: World Bank; 2016.

6. Díaz-Venegas C, Sáenz JL, Wong R. Family size and old-age wellbeing: Effects of the fertility transition in Mexico. Ageing Soc. 2017;37(3):495-516.

7. Wong R, Espinoza M. Ingreso y bienes de la población de edad media y avanzada en México. Papeles Poblac. 2003;9(37).

8. DeGraff DS, Wong R. Modeling old-age wealth with endogenous early-life outcomes: The case of Mexico. J Econ Ageing [Internet]. 2014 Apr [cited 2014 Aug 19];3:58-70. https://doi.org/10.1016/j. jeoa.2013.11.002

9. Wong R, Higgins M. Dynamics of intergenerational assistance in middle- and old-age in Mexico. In: Angel JL, Whitfield KE, editors. The Health of Aging Hispanics: The Mexican-Origin Population. New York: Springer-Verlag; 2007. p. 99-120.

10. Wong R, Michaels-Obregón A, Palloni A, Gutiérrez-Robledo LM, González-González C, López-Ortega M, et al. Progression of aging in Mexico: The Mexican health and aging study (MHAS) 2012. Salud Publica Mex. 2015;57:S79-89.

11. Damián A. Seguridad Social, Pensiones Y Pobreza De Los Adultos Mayores En México. Acta Sociol. 2016;70:151-72. https://doi. org /10.1016/j.acso.2017.01.007

12. DeGraff DS, Wong R, Orozco-Rocha K. Dynamics of Economic Security Among the Aging in Mexico: 2001-2012. Popul Res Policy Rev. 2018;37:59-90. https://doi.org/10.1007/s11113-017-9449-x

13. Wong R, Michaels-Obregon A, Palloni A. Cohort Profile: The Mexican Health and Aging Study (MHAS). Int J Epidemiol. 2017;46(2):e2(1-10).

14. Kim K, Zarit S, Fingerman K, Han G. Intergenerational Exchanges of Middle-Aged Adults With Their Parents and Parents-In-Law in Korea. J Marriage Fam. 2016;77(3):791-805.

15. Grundy E, Read S. Social contacts and receipt of help among older people in England: Are there benefits of having more children? J Gerontol B Psychol Sci Soc Sci. 2012;67(6):742-54.

16. Ciani E, Deiana C. No free lunch, buddy: past housing transfers and informal care later in life. Rev Econ Househ [Internet] 2018;(16):971-1001. https:/ /doi.org/10.1007/s11150-018-9417-1

17. Lambert F, Park H. Income Inequality and Government Transfers in Mexico. IMF Working Paper WP/19/148. Washington, DC: International Monetary Fund; 2019.

Manuscript submitted on 23 November 2020. Revised version accepted for publication on 2 March 2021. 


\section{La ayuda familiar recibida por las personas mayores mexicanas de todos los estratos socioeconómicos: cambios durante un decenio crítico}

RESUMEN Objetivo. Determinar la manera en que los modelos de apoyo económico familiar contribuyen a aliviar los efectos acumulativos de la desigualdad, haciendo especial hincapié en el apoyo financiero que los hijos brindan a sus padres ancianos.

Métodos. Esta investigación emplea datos de dos secciones transversales, del 2001 y del 2012, del estudio mexicano de salud y envejecimiento en una población de 50 años o más. El análisis incluye estadísticas descriptivas para calcular las diferencias de apoyo económico de acuerdo con las características individuales y familiares; y un modelo de regresión probit multinomial en cada corte transversal para analizar la cantidad de dinero que se ha recibido a modo de ayuda económica y las características asociadas.

Resultados. Entre el 2001 y el 2012, la ayuda económica recibida se redujo significativamente, tanto en la proporción, de $20 \%$ a $10 \%$, como en la cantidad recibida, con diferencias según el quintil de ingresos. En el 2001, un 14,9\% de las personas en el quintil más bajo (Q1) podían llegar a los quintiles Q4-Q5 con la ayuda de sus hijos; en el 2012, un 9,1\% de las personas. La probabilidad ajustada de recibir cualquier cantidad de dinero de los hijos disminuyó de 0,511 en el 2001 a 0,340 en el 2012.

Conclusiones. En México, la desigualdad económica en la población de 50 años o más sigue siendo una constante. La ayuda económica recibida por parte de los hijos ha variado según el quintil de ingresos y desempeña un papel esencial para las personas en los grupos de ingresos más bajos. Es necesario investigar más para comprender los modelos de los intercambios intergeneracionales a medida que estas cohortes de personas mayores envejecen y las futuras cohortes entran en la vejez con cambios más acusados que los que han sufrido las cohortes actuales durante este decenio crítico.

Palabras clave Familia; dinámica poblacional; economía; México.

\section{Ajuda da família a idosos no México em diferentes estratos socioeconômicos: a transformação ao longo de uma décadla crucial}

RESUMO Objetivo. Identificar como os padrões de auxílio econômico dos familiares contribuem para diminuir os efeitos cumulativos da desigualdade, com enfoque no auxílio financeiro dos filhos aos pais idosos.

Métodos. Este artigo se baseia em dados obtidos no Estudo de Envelhecimento e Saúde realizado em coortes transversais da população com 50 anos de idade ou mais no México, em 2001 e 2012. Estatísticas descritivas foram calculadas para estimar diferenças no auxílio financeiro segundo características individuais e familiares. Um modelo de regressão logística multinomial "probit" foi usado em cada iteração do estudo para analisar a quantia recebida na ajuda econômica e as características associadas.

Resultados. Entre 2001 e 2012, houve uma redução significativa da ajuda econômica, tanto em termos proporcionais (de $20 \%$ a $10 \%$ ) quanto em termos da quantia recebida, com diferenças por quintil de renda. Em 2001, 14,9\% das pessoas no quintil de renda mais baixo (Q1) ascendiam aos quintis Q4-Q5 com a ajuda dos filhos; em 2012, este percentual caiu para 9,1\%. Entre 2001 e 2012, a probabilidade ajustada de receber uma quantia em dinheiro dos filhos diminuiu de 0,511 para 0,340.

Conclusões. A desigualdade econômica na população com 50 anos ou mais no México é persistente. A ajuda econômica recebida dos filhos variou segundo o quintil de renda e é importante nas faixas de menor renda. Outros estudos são necessários para entender os padrões de intercâmbio intergeracional, já que estes idosos continuam envelhecendo e as coortes futuras avançam em idade e se defrontarão com transformações ainda maiores que as enfrentadas pelas coortes atuais ao longo desta década crucial.

Palavras-chave Família; dinâmica populacional; economia; México. 